$\mathrm{Nr} 8$

WARSZAWA-KRAKÓW 2006

ZBIGNIEW MAKIEŁA

Akademia Pedagogiczna, Kraków

\title{
Funkcjonowanie Przedsiębiorstwa Poszukiwań i Eksploatacji Złóż Ropy Naftowej i Gazu Petrobaltic w okresie transformacji gospodarczej na tle rozwoju przemysłu naftowego
}

\author{
ROZWÓJ PRZEMYSŁU NAFTOWEGO W POLSCE
}

Górnictwo ropy naftowej i gazu ziemnego w Polsce należy do najstarszych na świecie przemysłów naftowych wydobywających ropę i gaz metodami wiertniczymi. Początek zorganizowanego przemysłu naftowego w Polsce przypada na rok 1852, kiedy Ignacy Łukasiewicz przeprowadził pierwszą destylację ropy otrzymując $\mathrm{z}$ niej naftę, którą następnie w 1853 roku zastosował jako paliwo do skonstruowanej przez siebie lampy naftowej (Ney 1973). W 1854 r. powstała pierwsza w Polsce kopalnia ropy naftowej w Bóbrce, a w roku 1855 pierwsza rafineria ropy (,destylarnia”, jak wówczas nazywano) w Klęczanach k. Grybowa, założona przez I. Łukasiewicza. Początkowo metody wydobywania ropy naftowej były bardzo prymitywne. Pierwsze szyby stanowiły kopane ręcznie studnie, głębokości kilkudziesięciu metrów, tzw. kopanki. Ropę wydobywano z nich przez łyżkowanie, przy pomocy ręcznych kołowrotów. Jeden z pierwszych w Polsce kopany ręcznie szyb „Franek” zachował się do dziś na terenie kopalni w Bóbrce, gdzie obecnie znajduje się Muzeum Polskiego Przemysłu Naftowego.

Badania naukowe nad poszukiwaniem i wykorzystaniem ropy naftowej najwcześniej rozwinęły się w Polsce i stały się podstawą do rozwoju przemysłu naftowego, co dało impuls do rozwoju tego przemysłu na świecie. Następnym obszarem badań i poszukiwań naftowych stały tereny Rosji i Stanów Zjednoczonych (Ney 1973). Postęp techniczny w metodach poszukiwania ropy poprzez stosowanie odwiertów od 1859 roku przyczynił się do intensyfikacji poszukiwań, co spowodowało wzrost wydobycia ropy naftowej w Polsce (tab. 1) i na świecie.

Poszukiwania geologiczne przyczyniły się do odkrycia nowych złóż na całym niemal Podkarpaciu. Chronologię nawierconych nowych złóż przedstawia tabela 2. 
Tabela 1. Wydobycie ropy naftowej w Polsce w latach 1859-1917

\begin{tabular}{|c|c|c|}
\hline Rok & w tys. ton & $\begin{array}{c}\text { Dynamika } \\
\text { Rok poprzedni }=100\end{array}$ \\
\hline 1885 & 65 & 100,0 \\
\hline 1907 & 1000 & 153,8 \\
\hline 1914 & 655,6 & 65,6 \\
\hline 1915 & 676 & 103,1 \\
\hline 1917 & 849 & 125,6 \\
\hline
\end{tabular}

Źródło: opracowanie własne

Tabela 2. Złoża ropy naftowej i gazu ziemnego odkryte w latach 1883-1913

\begin{tabular}{|c|l|c|}
\hline Lp. & \multicolumn{1}{|c|}{ Obszar wydobycia } & Data \\
\hline 1. & Turzepole-Zmiennica & 1883 \\
\hline 2. & Wańkowa, Potok & 1885 \\
\hline 3. & Krościenko, Majdan, Pasieczna, Strzelbice & 1886 \\
\hline 4. & Biecz & 1887 \\
\hline 5. & Węglówka & 1888 \\
\hline 6. & Rudawka Rymanowska & 1889 \\
\hline 7. & Iwonicz Zdrój, Rypno, Schodnica & 1890 \\
\hline 8. & Kobylany & 1891 \\
\hline 9. & Turaszówka & 1892 \\
\hline 10. & Tustanowice, Urycz & 1895 \\
\hline 11. & Stara Wieś & 1896 \\
\hline 12. & Grabownica & 1898 \\
\hline 13. & Bitków, Kosmacz & 1899 \\
\hline 14. & Tarnawa Wielopole & 1900 \\
\hline 15. & Mraźnica & 1911 \\
\hline 16. & Mokre & 1913 \\
\hline
\end{tabular}

Źródło: J. Sozański 1996

Okres 1883-1913 był pomyślny dla rozwoju przemysłu przetwórstwa ropy naftowej. W tym czasie na Podkarpaciu powstało około 60 małych destylarni i rafinerii. Niektóre $\mathrm{z}$ nich $\mathrm{w}$ wyniku modernizacji i rozbudowy w unowocześnionym kształcie przetrwały po dzień dzisiejszy. Są to m.in. rafinerie w Gliniku Mariampolskim (1886), Jaśle (1888), Targowiskach (1890), Jedliczu (1902), Krośnie (1905), Drohobyczu (1912). Szybki rozwój przemysłu naftowego dał początek budowy przemysłu maszyn górniczych oraz tworzenia zaplecza naprawczego, którego zadaniem było wytwarzanie, konserwacja maszyn i urządzeń górniczych. Rozwój postępu technicznego i technologicznego w tej dziedzinie wytwórczości spowodował, że polski przemysł naftowy należał w tym okresie do nowoczesnych gałęzi przemysłu i stał się motorem rozwoju gospodarczego regionu Podkarpacia. Istotnym czynnikiem wspierającym ten proces był dopływ do przemysłu naftowego wysoko wykształconych specjalistów. Polscy inżynierowie kształcili się w renomowanych uczelniach górniczych w Freiburgu, Leoben i w wyższych uczelniach technicznych Lwowa, Pragi, Wiednia. Rozbudowa zagłębia naftowego była istotnym czynnikiem lokalizacji przy podejmowaniu decyzji o budowie Centralnego Okręgu Przemysłowego w widłach Wisły i Sanu. Bliskość zaplecza energetycznego uniezależniała powstający okręg przemysłowy od importu surowców energetycznych. 
W okresie międzywojennym wydobycie ropy naftowej wykazywało tendencję spadkową, spowodowaną wieloma czynnikami. Jednym z nich był okres kryzysu światowego. Spowodował on zmniejszenie nakładów na poszukiwania nowych złóż ropy naftowej, a także zmniejszenia jej wydobycia z eksploatowanych odwiertów oraz mniejszy popyt ubożejącego społeczeństwa na produkty przetwórstwa ropy naftowej.

Tabela 3. Wydobycie ropy w Polsce w latach 1919-1940

\begin{tabular}{|c|c|c|}
\hline Rok & tys. ton & $\begin{array}{c}\text { Dynamika } \\
\text { Rok poprzedni }=100\end{array}$ \\
\hline 1919 & 830 & 100 \\
\hline 1925 & 812 & 97,8 \\
\hline 1930 & 663 & 81,7 \\
\hline 1938 & 553 & 83,4 \\
\hline 1940 & 400 & 72,3 \\
\hline
\end{tabular}

Źródło: J. Sozański 1996

Pod koniec okresu międzywojennego, w latach 1928-1939 następuje rozszerzenie obszaru poszukiwań ropy naftowej na teren Gór Świętokrzyskich, rejonu Tarnowa i Niżu Polskiego (tab. 4).

Tabela 4. Złoża ropy naftowej odkryte w latach 1929-1939

\begin{tabular}{|c|l|c|}
\hline Lp. & \multicolumn{1}{|c|}{ Obszar wydobycia } & Data \\
\hline 1. & Roztoki & 1929 \\
\hline 2. & Rzepiennik, Tyrawa Solna & 1930 \\
\hline 3. & Magdalena & 1931 \\
\hline 4. & Sanok-Zabłocie & 1933 \\
\hline 5. & Bystre & 1934 \\
\hline 6. & Dolina & 1935 \\
\hline 7. & Czarna, Lipie, Fellnerówka-Hanka & 1936 \\
\hline 8. & Szalowa-Heddy & 1939 \\
\hline
\end{tabular}

Źródło: J. Sozański 1996

Po II wojnie światowej nastąpiła intensyfikacja poszukiwań nowych złóż ropy naftowej i gazu ziemnego również poza obszarem Karpat. W ich wyniku nawiercono i zagospodarowano nowe złoża ropy naftowej na Podgórzu i Monoklinie Przedsudeckiej, w rejonie Wału Kujawskiego oraz na Bałtyku. Szczególne znaczenie dla wydobycia ropy naftowej i gazu ziemnego maja tereny roponośne w rejonie Partyni (1958), Dębicy (1969), Grobli i Pławowic, Rybak (1961), Maszewa (1970), Sulęcina (1973), Kostrzynia (1991), Kamienia Pomorskiego i Żarnowca (1972), Gorzysławia i na Wyspie Wolin, Daszewa-Karlina (1980), Świdnika (1981) i szelfu Morza Bałtyckiego (1992) (tab. 5).

Poszukiwania ropy naftowej i gazu ziemnego w okresie powojennym charakteryzują się szybkim wzrostem liczby odwiertów (ok. 20 tys. o łącznej głębokości ponad 10 tys. km) i profili sejsmicznych (ok. 250 tys. km). Słabą stroną tych przedsięwzięć jest niedoskonałość techniczna i technologiczna, odwierty są zbyt płytkie (nie przekraczają $10 \mathrm{~km}$ głębokości), co powoduje, że uzyskiwane efekty były niewielkie, świadczy o tym wielkość wydobywanej ropy naftowej. Prowadzone prace geologiczne i wiertnicze doprowadziły jednak do odkrycia około 250 nowych złóż ropy naftowej i gazu ziemnego. Niewielki poziom wydobycia ropy naftowej i gazu ziemnego był czynnikiem ograniczającym rozwój przemysłu petrochemicznego na południu Polski. 
Tabela 5. Wydobycie ropy naftowej w latach 1950-2000

\begin{tabular}{|c|c|c|}
\hline Rok & tys. ton & $\begin{array}{c}\text { Dynamika } \\
\text { Rok poprzedni=100 }\end{array}$ \\
\hline 1950 & 161,9 & 100,0 \\
\hline 1960 & 194,4 & 120,0 \\
\hline 1970 & 424 & 218,0 \\
\hline 1980 & 329 & 77,6 \\
\hline 1990 & 163 & 49,5 \\
\hline 2000 & 653 & 400,0 \\
\hline 2001 & 767 & 117,4 \\
\hline 2002 & 728 & 94,9 \\
\hline
\end{tabular}

Źródło: Rocznik Statystyczny GUS, Warszawa

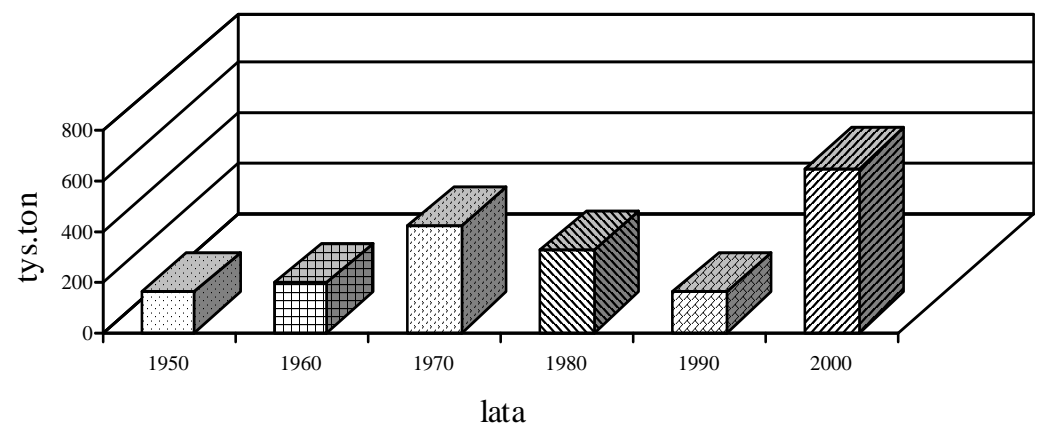

Ryc. 1 . Wydobycie ropy naftowej

Rozwój gospodarki kraju wykazywał coraz większe zapotrzebowanie na surowce energetyczne, w tym szczególnie na ropę naftową. Z tego m.in. powodu Polska systematycznie zwiększała import ropy naftowej ze złóż położonych na terytorium ówczesnego ZSRR. W tym celu w 1964 roku przez terytorium Polski ukończono budowę ropociągu „Przyjaźń”, a na trasie jego przebiegu zlokalizowano największą w Polsce rafinerię ropy naftowej w Płocku, o potencjale przetwórczym ponad $6 \mathrm{mln}$ ton ropy naftowej rocznie. W późniejszym czasie, po jej rozbudowie, potencjał przetwórczy rafinerii wzrósł do $12 \mathrm{mln}$ t. Rosnące zapotrzebowanie polskiej gospodarki na ropę naftową wymuszało wzrost importu. Celem dywersyfikacji źródeł zaopatrzenia w ropę w latach 70. Polska rozpoczęła import z krajów arabskich. Transport ropy do Gdańska odbywał się drogą morską, tankowcami o wyporności ponad 300 tys. BRT. Dla przetwórstwa ropy naftowej importowanej z krajów arabskich wybudowano w Gdańsku rafinerię, a w Porcie Północnym nabrzeże portowe dla jej przesyłu z tankowców cumujących na Bałtyku. 


\section{OBSZARY POSZUKIWAŃ ROPY NAFTOWEJ}

Aktualnie prace poszukiwawcze ropy naftowej na obszarze Polski prowadzone są przez spółkę Polskie Górnictwo Naftowe i Gazownictwo S.A na lądzie i firmę Petrobaltic w polskiej strefie ekonomicznej Morza Bałtyckiego. Na początku lat 90. obszar Polski stał się miejscem intensywnych poszukiwań ropy naftowej także przez zagraniczne firmy naf-towe. Celem porządkowania struktury przestrzennej poszukiwań złóż ropy naftowej tery-torium Polski podzielono na koncesjonowane pola naftowe, a w wyniku przeprowadzonych przetargów koncesje na poszukiwania ropy naftowej przyznano dwóm polskim przedsiębiorstwom (PGNiG S.A., Petrobaltic) i kilku znanym firmom zagranicznym, w tym FX Energy, Wielkopolska Energia (Texaco+El Paso), Texaco, Exxon-Shell, Calenergy, RweDea, Apache, Meduza.

Koncesję i największy obszar (około 30 tys. km 2) poszukiwań przyznano firmie polskiej PGNiG S.A. Obszar koncesyjny koncentruje się na terenie Karpat, Przedgórza, Zachodniej Polski oraz w mniejszym zakresie na Pomorzu i Lubelszczyźnie. Koncesję na poszukiwania ropy naftowej na obszarze morskim przyznano polskiej firmie Petrobaltic.

\section{GENEZA I KSZTAŁTOWANIE SIĘ PRZEDSIĘBIORSTWA POSZUKIWAŃ I EKSPLOATACJI ZŁÓŻ Ropy I GAZU PETROBALTIC}

Przedsiębiorstwo Poszukiwań i Eksploatacji Złóż Ropy i Gazu Petrobaltic powstało w latach 60. XX stulecia. Pierwsze prace związane z poszukiwaniami naftowymi prowadziła w polskiej strefie ekonomicznej w latach 1964-67 ekspedycja radziecka. Wykonano wówczas rekonesansowe prace sejsmiczne, które przyczyniły się do rozpoznania budowy geologicznej południowego Bałtyku. Efektem tych prac było wydzielenie 8 bloków strukturalnych z perspektywą eksploatacji ropy naftowej. Intensyfikacja prac geologicznych (regionalne, a następnie szczegółowe badania sejsmiczne, wiercenia) południowego Bałtyku przypadły na rok 1975 i były już prowadzone przez Wspólną Organizację Poszukiwań Naftowych na Morzu Bałtyckim Petrobaltic, której udziałowcami była Polska, NRD i ZSRR. Pomimo poszerzenia obszaru poszukiwań o obszar Platformy Epikaledońskiej wiercenia nie przyniosły oczekiwanych odkryć. Potwierdziły jedynie istnienie kompleksów osadowych skał macierzystych i zbiornikowych o stwierdzonych już akumulacjach ropy i gazu. W wyniku przemian polityczno-społecznych w krajach Europy Środkowej, rozpadu ZSRR i włączenia NRD do struktur RFN w 1990 r. Wspólna Organizacja Poszukiwań Naftowych na Bałtyku została zlikwidowana.

W celu kontynuacji prac poszukiwawczych w polskiej strefie ekonomicznej Bałtyku podjęto decyzję o utworzeniu firmy poszukiwawczej złóż ropy naftowej. 27 listopada 1990 r. Minister Przemysłu i Handlu powołał Przedsiębiorstwo Poszukiwań i Eksploatacji Złóż Ropy i Gazu Petrobaltic. Firma ta, bazująca na dotychczasowych doświadczeniach i wykorzystująca dorobek badawczy oraz majątek produkcyjny likwidowanej międzynarodowej, podjęła działalność gospodarczą. Z funduszy Ministerstwa Przemysłu i Handlu otrzymała 
środki finansowe na wykup urządzeń i sprzętu niezbędnego do kontynuowania prac. Intensyfikacja prac poszukiwawczych przyniosła wymierne efekty, w maju 1992 roku zaczęto wydobywać ropę naftową w polskiej strefie ekonomicznej Morza Bałtyckiego, a pierwszy zbiornikowiec z ładunkiem ropy wydobytej na terenie morskim RP wpłynął do Portu Północnego 26 czerwca $1992 \mathrm{r}$.

Uzyskane środki finansowe ze sprzedaży ropy naftowej w całości przeznaczono na dozbrojenie morskiej infrastruktury wydobycia ropy naftowej. Uruchomienie nowych otworów pozwoliło na osiągnięcia stabilnego poziomu wydobycia ropy naftowej w wysokości około 320 ton/dobę (2500 baryłek). Dalszy rozwój firmy pozwalał na poszerzenie obszaru poszukiwania ropy naftowej i gazu oraz rozbudowę potencjału produkcyjnego. Dla realizacji tego celu wydzierżawiono na okres dwóch lat od norweskiej firmy Smedvig platformę wiertniczą West Beta, którą przyholowano z Adriatyku i posadowiono na złożu.

Podjęte działania inwestycyjne przyczyniły się do intensyfikacji poszukiwań i na przełomie sierpnia i września 1995 r. rozpoczęto eksploatację złoża ropy naftowej na skalę przemysłową. Podpisano również umowę z Ministrem Ochrony Środowiska o ustanowienie pola górniczego o powierzchni ponad 7 tys. $\mathrm{km}^{2}$. Zwiększenie obszaru koncesyjnego wymagało koncentracji potencjału wydobywczego firmy. W tym celu podjęto decyzję o zakupie używanej platformy Petrobaltic. Kolejną inwestycją był zakup używanej platformy wiertniczej West Beta, którą zarejestrowano pod polską banderą pod nazwą Baltic Beta. Dalszy rozwój firmy związany był z poszerzeniem obszaru badań na dnie Morza Bałtyckiego, tj. nawierceniem otworów kierunkowych o nazwie B3-15, B3-16, B3-17, z których już w 1996 r. rozpoczęto wydobycie. Rok później od holenderskiego armatora zakupiono statek ratowniczy Aphrodite I.

W grudniu 1998 roku doszło do podpisania przez Ministra Skarbu Państwa aktu komercjalizacji przedsiębiorstwa i przekształcenie go w spółkę z ograniczoną odpowiedzialnością, której jedynym udziałowcem był Skarb Państwa. W tym samym miesiącu spółka została wpisana do Krajowego Rejestru Sądowego pod numerem H/B 13424 oraz wykreślona z rejestru przedsiębiorstw państwowych. Od 1 stycznia 1999 roku pod nową nazwą rozpoczyna działalność Przedsiębiorstwo Poszukiwań i Eksploatacji Złóż Ropy i Gazu Petrobaltic sp. z o.o. W 1998 r. utworzono na Cyprze spółkę zależną ze 100\% udziałem Petrobalticu, pod nazwą Miliana Shipping Company Ltd.

O ekspansji rozwojowej firmy świadczy zakup Icarus II i wyczarterowanie tankowca bandery maltańskiej m/t Nunki. Równocześnie odnowiona zostaje koncesja na pięć lat dla platformy Petrobaltic i platformy Baltic Beta. W listopadzie 1999 r. przedstawiciele firmy podpisują list intencyjny z niemiecką firmą Erdöel-Erdgas Gommern GmbH dotyczący wzajemnej współpracy przy zagospodarowaniu złóż gazowych.

Pod koniec 1999 roku Petrobaltic kupił wspólnie ze Spółką Energobaltic ziemię we Władysławowie (od przedsiębiorstwa Szkuner) pod budowę ekologicznej elektrociepłowni. Decyzja o budowie elektrociepłowni związana była z koniecznością wykorzystania gazu ziemnego wydobywanego z dna Bałtyku. Budowa elektrociepłowni realizowana jest przez kilka firm międzynarodowych, tj. Petrobaltic (45\% udziałów), Energobaltic (5\%), Rolls Royce Power Ventures Ltd (40\%) i Hydromex sp. z o.o. (10\%). W lipcu 2000 r. przedsiębiorstwo Petrobaltic kupiło pakiet akcji konsorcjum UAB Naftos Gavyba z siedzibą na Litwie, a następnie akcje litewskiej firmy naftowej AB Geonafta. Trzy miesiące później pozyskało dominujący pakiet akcji $(80,84 \%)$ litewskiej firmy, formalnie przejmując zarządzanie firmą. Kolejnym kierunkiem działania Petrobalticu są prowadzone poszukiwania i zagospodarowanie już istniejących złóż gazu ziemnego. Dla realizacji tych projektów firma Petrobaltic podjęła 
współpracę z CalEnergy Gas sp. z o.o. (Polska) w zakresie wspólnych działań na obszarze koncesyjnym „Piła” oraz podpisano umowę z firmami GDFI i Erdgas-Erdöel GmbH-Berlin dotyczącą rozpoznania złóż gazu ziemnego w obrębie obszaru koncesji firmy Petrobaltic na Morzu Bałtyckim.

W 2001 r. dla samodzielnego prowadzenia prac geologicznych i sejsmicznych zakupiono statek badawczy Santa Barbara bandery St.Vincent and the Grenadines. Statek zakupiony został przez armatora cypryjskiego Miliana Shiping Company Ltd., którego głównym udziałowcem jest Petrobaltic sp. z o.o.). Jako właściciel statku badawczego firma Petrobaltic stała się samodzielnym podmiotem mogącym prowadzić działalność badawczą i eksploa-tacyjną w zakresie poszukiwań i eksploatacji ropy naftowej. Następnym etapem w rozwoju firmy był zakup śmigłowca transportowego Mi 17, który służy do transportu pracowników spółki na platformy wiertnicze. Wraz z rozwojem firmy wzrasta liczba pracowników biorących bezpośredni udział w eksploatacji złóż ropy naftowej, a także pracowników pionu naukowobadawczego (tab. 6). Koncentracja potencjału produkcyjnego firmy, przemiany organizacyjne i zmiany $\mathrm{w}$ zarządzaniu przedsiębiorstwem w istotny sposób wpłynęły na systematyczny wzrost wydobycia ropy naftowej (tab. 7).

Tabela 6. Wielkość zatrudnienia w latach 1995-2002

\begin{tabular}{|l|c|c|c|c|c|c|c|c|}
\hline \multicolumn{1}{|c|}{ Rok } & 1995 & 1996 & 1997 & 1998 & 1999 & 2000 & 2001 & 2002 \\
\hline $\begin{array}{l}\text { Liczba zatrudnio- } \\
\text { nych ogółem }\end{array}$ & 400 & 437 & 458 & 438 & 375 & 420 & 435 & 465 \\
\hline $\begin{array}{l}\text { Dynamika } \\
\text { Rok poprzedni=100 }\end{array}$ & 100 & 109,2 & 104,5 & 95,6 & 85,6 & 112 & 103,6 & 106,9 \\
\hline- w tym na morzu & 220 & 226 & 231 & 228 & 208 & 218 & 222 & 225 \\
\hline
\end{tabular}

Źródło: Materiały informacyjne Petrobaltic Sp. z o.o.

Tabela 7. Wydobycie ropy naftowej w latach 1992-2002

\begin{tabular}{|c|c|c|c|}
\hline Rok & $\begin{array}{c}\text { Wydobycie } \\
\text { (w tys. ton) }\end{array}$ & $\begin{array}{c}\text { \% udział } \\
\text { w wydobyciu } \\
\text { krajowym }\end{array}$ & $\begin{array}{c}\text { Dynamika } \\
1992=100\end{array}$ \\
\hline 1992 & 20,2 & 10,1 & 100 \\
\hline 1993 & 54,1 & 23,0 & 267,8 \\
\hline 1994 & 86,1 & 30,3 & 426,2 \\
\hline 1995 & 112,0 & 38,4 & 554,4 \\
\hline 1996 & 148,0 & 46,7 & 732,6 \\
\hline 1997 & 113,6 & 38,1 & 562,4 \\
\hline 1998 & 164,4 & 46,1 & 813,8 \\
\hline 1999 & 239,2 & 56,3 & 1184,0 \\
\hline 2000 & 284,0 & 43,5 & 1406,0 \\
\hline 2001 & 284,5 & 31,1 & 1408,0 \\
\hline 2002 & 284,9 & 39,1 & 1410,0 \\
\hline
\end{tabular}

Źródło: Roczniki Statystyczne 1992-2003 GUS, Warszawa 
PERSPEKTYWY ROZWOJU PRZEDSIĘBIORSTWA PETROBALTIC

Głównym celem działalności przedsiębiorstwa jest podnoszenie jego konkurencyjności na rynku krajowym i rynkach międzynarodowych. Dla uzyskania przewagi konkurencyjnej rozpoczęto realizować opracowaną strategię działania na najbliższe lata. Wybrane elementy strategii realizowana będzie dwutorowo:

- prowadzenie prac poszukiwawczych i rozpoznawczych nowych złóż ropy naftowej i gazu ziemnego na obszarze koncesji oraz wykonanie otworów poszukiwawczych i rozpoznawczych w morskiej strefie ekonomicznej RP. Firma planuje zwiększenie wydobycia ropy naftowej w ciagu 5 lat, do 500 tys. ton rocznie. Natomiast wydobycie gazu ziemnego planowane jest $\mathrm{w}$ wysokości około $36 \mathrm{mln} \mathrm{m}^{3}$ rocznie, przez okres $12-15$ lat z przeznaczeniem dla budowanie elektrociepłowni we Władysławowie;

- powiększenie obszaru działania firmy poza granice RP. Podjęto działania na rzecz współpracy ze służbami geologicznymi Litwy i Łotwy w zakresie prac poszukiwawczych w obszarach morskich i lądowych tych państw. Ponadto nawiązano współpracę z krajami Azji PołudniowoWschodniej oraz Afryki Zachodniej, które powinny zaowocować udziałem Polski w eksploatacji najbardziej perspektywicznych złóż roponośnych świata.

\section{PLANOWANE INWESTYCJE - PROJEKT \\ ELEKTROCIEPŁOWNI „WŁADYSŁAWOWO”}

Budowa elektrociepłowni we Władysławowie, opartej na wykorzystaniu gazu ziemnego z dna Bałtyku, realizowana jest przez utworzoną dla tego celu w 1997 r. spółkę Energobaltic, której udziałowcami są przedsiębiorstwa Petrobaltic, Hydromex i firma Rolls Royce Power Ventures Władysławowo z Wielkiej Brytanii. Inwestycja podzielona została na dwa etapy. Pierwszy obejmuje budowę miejskiej sieci ciepłowniczej o łącznej długości ponad $10 \mathrm{~km}$, w tym także instalację kosztochłonnych węzłów ciepłowniczych. W drugim etapie budowy planuje się uruchomienie stacji sprężania i przygotowania gazu do transportu z morza na ląd, a na platformie Baltic Beta planuje się uruchomienie stacji separacji i odzysku gazu. Budowa nowoczesnej ekologicznej elektrociepłowni jest przedsięwzięciem wpisanym w program ochrony ekosystemu obszaru Bałtyku. Przedsięwzięcie to przyczyni się do likwidacji około 100 istniejących we Władysławowie kotłowni opalanych węglem i olejem opałowym. Ponadto energia cieplna uzyskana w elektrociepłowni „Władysławowo” z gazu z podmorskich złóż będzie tańsza o około $25 \%$ od energii z tradycyjnych elektrociepłowni.

\section{Literatura}

Karlic S., 1983, Zarys górnictwa morskiego, Wydawnictwo „Śląsk”, Katowice Liszka K., 1972, Eksploatacja złóż ropy naftowej, PWN, Warszawa

Ney R. (red.), 1973, Poszukiwanie i rozpoznanie złóż ropy naftowej i gazu ziemnego, Wydawnictwa Geologiczne, Warszawa

Sozański J., 1996, Bóbrka - naftowe dziedzictwo, Krosno 